\title{
WPEYW POLITYKI PODATKOWEJ STANÓW ZJEDNOCZONYCH NA WZROST NIERÓWNOŚCI DOCHODOWYCH SPOŁECZEŃSTWA AMERYKAŃSKIEGO W LATACH 1975-2008
}

\section{WSTĘP}

Śmierć i podatki - to według powiedzenia dwie nieuchronne rzeczy w życiu każdego człowieka. Artykuł ten nie jest bynajmniej próbą zaprzeczenia jednemu bądź drugiemu, ale jedynie próbą weryfikacji uzasadnienia, dlaczego tak być musi, że podatki są konieczne. Uzasadnienia, na które powołuje się państwo, jako strona wymierzająca podatki, pobierająca je i dysponująca dochodami pochodzącymi właśnie z podatków.

Wielu autorów, omawiając funkcje podatków, czy też szerzej - finansów publicznych, odwołuje się do ich trzech funkcji: redystrybucyjnej, alokacyjnej i stabilizacyjnej ${ }^{1}$. Takie zadania są powierzane podatkom, a przede wszystkim państwu, jako ich wykonawcy. Od ogólnej koncepcji polityki gospodarczej obieranej przez daną administrację rządową zależy, jak i czy faktycznie te funkcje są wypełniane. Szczególny nacisk w tym artykule położony został na wypełnianie funkcji wyrównywania nierówności dochodowych w społeczeństwie za pomocą systemu podatków od dochodów indywidualnych, w ramach funkcji redystrybucyjnej finansów publicznych.

Artykuł przedstawia analizę systemu podatków od dochodów osobistych w latach 1980-2008² w Stanach Zjednoczonych oraz ich wpływu na nierówności dochodowe. Zastosowano metodę opisową wspartą o dane i obliczenia statystyczne.

${ }^{1}$ A. Komar, Finanse publiczne w gospodarce rynkowej, Oficyna Wydawnicza Branta, Bydgoszcz 1996, s. 63.

${ }^{2} \mathrm{Z}$ uwzględnieniem stanu wyjściowego, za który przyjęto rok 1975. 


\section{SYSTEM PODATKOWY STANÓW ZJEDNOCZONYCH - WPROWADZENIE}

Federalny system podatkowy (Internal Revenue Service) został utworzony w 1913 roku. Od tego czasu system podatków od dochodów osobistych przeszedł bardzo wiele zmian w różnych, często przeciwnych kierunkach: od 56 progów podatkowych w roku 1918, do $3 \mathrm{w}$ roku 1990; od 94\% jako stopy podatkowej ostatniego przedziału dochodów w roku 1944, do 28\% w roku 19883. Właśnie w latach 80 . stał się to system wyraźnie uprzywilejowujący bogatych.

Amerykański system podatków od dochodów osobistych wyróżnia cztery kategorie statusu zeznaniowego:

- osoby pozostające w związku małżeńskim wypełniające wspólnie zeznanie podatkowe oraz żyjący współmałżonkowie (Married Filing Jointly);

- głowy gospodarstw domowych (Head of Household);

- osoby samotne (Single);

- osoby pozostające w związku małżeńskim wypełniające odrębne zeznania podatkowe (Married Filing Separately).

Należy w tym miejscu dodać, że dodatkowy ciężar opodatkowania dochodów indywidualnych stanowią dodatkowe podatki nakładane przez stany i jednostki samorządu terytorialnego. Stawki te są zróżnicowane, jednak nie są one wysokie.

\section{ODWRÓT OD INTERWENCJONIZMU}

Sięgnięcie do okresu historii gospodarczej Stanów Zjednoczonych poprzedzającego okres objęty analizą w tym artykule uzasadnić należy w ten sposób, że to właśnie wtedy, w latach 70., doszło do ujawnienia się takich zjawisk gospodarczych, których wyjaśnienie przyniosła dopiero teoria ekonomii ówczesnego okresu. Teoria, której idee przyświecały i zalecane rozwiązania stosowane były przez cały okres objęty analizą.

Właśnie lata 70. XX wieku przyniosły spowolnienie gospodarki amerykańskiej, któremu towarzyszyła rosnąca inflacja. Sytuacji znikomego bądź nawet zerowego wzrostu gospodarczego i rosnącej inflacji ${ }^{5}$ nie potrafiła wytłumaczyć teoria Keynesa. Do tego doszło jeszcze rosnące w coraz szybszym tempie bezrobocie - w latach 1974-1980 rocznie wynosiło ono średnio 6,8\%. Nadal próbowano walczyć z bezrobociem, zwiększając podaż pieniądza, jednak krzywa Phillipsa,

\footnotetext{
${ }^{3}$ Tax Foundation.

${ }^{4}$ I. Mirek, System podatkowy Stanów Zjednoczonych, http://biurose.sejm.gov.pl/teksty_pdf/e278.pdf (10.09.2009).

${ }^{5}$ To wówczas upowszechniło się nowe określenie tego zjawiska - slumpflacja.
} 
opisująca negatywną zależność między inflacją i bezrobociem, w latach 70. „straciła swoją wiarygodność"

Występowanie opisanych wyżej wskaźników w gospodarce amerykańskiej lat 70. było wystarczającym asumptem do rozwoju badań i nowych koncepcji ekonomicznych ${ }^{7}$. Już w 1967 roku Milton Friedman tłumaczył wysoką inflację rosnącą podażą pieniądza prezentując odpowiednie szeregi czasowe. Potwierdzanie się wniosków Friedmana także przez całe lata 70. spowodowało, że poglądy monetarystów były kwestionowane coraz słabiej. Twierdzili oni, że polityka szerokiej ingerencji państwa w gospodarkę jest mało efektywna i do tego bardzo kosztowna. W sukurs poglądom monetarystów odnośnie do inflacji szła szkoła racjonalnych oczekiwań. Przedstawiciele tej szkoły postulowali stabilną, przejrzystą i długofalową politykę kreacji pieniądza, jako zdecydowanie sprzyjającą redukcji niepewności na rynku, np. inflacji, i przez to podnoszącą jej ogólną efektywność. Monetaryści i przedstawiciele szkoły racjonalnych oczekiwań zgadzali się także co do najskuteczniejszego instrumentu walki z inflacją - polityki pieniężnej.

W kwestiach podatkowych największy rozgłos wśród nowych teorii uzyskała szkoła ekonomii podażowej (supply-side economics). Wysunęła ona cztery krytyczne wnioski co do ówczesnego systemu podatkowego:

- sprawiedliwy i prosty system podatkowy, pozbawiony przeróżnych ulg podatkowych (prowadzących do zmniejszania podstawy opodatkowania), mógłby zapewnić wyższe dochody do budżetu nawet przy niższej stawce;

- ulgi podatkowe wywołują silne efekty zniekształcające zachowania podmiotów gospodarczych;

\footnotetext{
${ }^{6}$ Określenie Bieńkowskiego: W. Bieńkowski, Reaganomika i jej wpływ na konkurencyjność gospodarki amerykańskiej, Wydawnictwo Naukowe PWN, Warszawa 1995, s. 105.

${ }^{7}$ Oprócz opisanych niżej ogólnych poglądów i postulatów szkoły podażowej, monetarystów i szkoły racjonalnych oczekiwań, za generalnym zmniejszeniem udziału państwa w gospodarce opowiadali się także twórcy teorii government failure i public choice. Zaznaczyć jednak należy, że odwrót od interwencjonizmu nie był wówczas jedyną koncepcją zwalczenia rosnących trudności gospodarczych. Jak pisze S. F. Hayward, jeszcze podczas wyborów w 1976 r. jeden z punktów programu demokratów głosił, że „szczególną wagę należy przywiązywać do możliwości zastosowania centralnego planowania w gospodarce". W dokonanym przez Haywarda opisie ówczesnej dyskusji na temat kierunku, jaki należy obrać w polityce gospodarczej, wyczuć można napięcie i obawy, w którą stronę najpotężniejsza gospodarka świata podąży. Prezydent Jimmy Carter wraz ze swoją administracją poczynili kroki zmierzające do wzrostu ingerencji państwa w gospodarkę, jednak osiągane przez nich wyniki gospodarcze (przede wszystkim rosnąca wciąż inflacja) doprowadziły do bankructwa tej polityki i zwrotu w stronę deregulacji rynku wraz z wyborami prezydenckimi w 1980 r. S. F. Hayward, Ewolucja polityki spoteczno-gospodarczej Stanów Zjednoczonych w latach 80. XX wieku, [w:] W. Bieńkowski, M. Radło (red.), Amerykański model rozwoju gospodarczego - istota, efektywność $i$ możliwość zastosowania, Szkoła Główna Handlowa w Warszawie, Warszawa 2006, s. 77.
} 
- progresja podatkowa działa demobilizująco, zarówno na chęć do $\operatorname{pracy}^{8}$, jak $\mathrm{i}$ inwestowania; niższe podatki i prosty system podatkowy motywują do pracy (wzrost podaży pracy), co z kolei powoduje zwiększenie ogólnej podstawy opodatkowania, zwiększając w konsekwencji wpływy do budżetu;

- inflacja prowadzi do wzrostu opodatkowania dochodów na skutek wzrostu płac nominalnych ${ }^{9}$ a to prowadzi do osłabienia bodźców do pracy ${ }^{10}$.

Opisane wyżej postulaty wskazują na zdecydowane przeniesienie punktu ciężkości w prowadzonej polityce. Oznaczają one odejście od keynesowskiego sterowania popytem w kierunku poglądów postulujących tworzenie i stymulowanie bodźców powodujących zwiększanie podaży czynników produkcji. Także bardzo znamienne było przeniesienie koncentracji w polityce makroekonomicznej z bezrobocia i polityki pełnego zatrudnienia (Employment Act z 1946 roku) na inflacje i politykę antyinflacyjną jako najistotniejszą oraz przeniesienie horyzontu polityki makroekonomicznej z krótkookresowego do długookresowego ${ }^{11}$. Te zmiany spojrzenia na politykę podatkową wpisują się jednak w znacznie szerszą ideę ograniczonego do koniecznego minimum udziału państwa w gospodarce. Te poglądy przystawały także do tradycyjnie prorynkowych i antyinterwencjonistycznych poglądów partii republikańskiej. Szybko zatem idee szkoły podażowej stały się osią programu gospodarczego Ronalda Reagana.

\section{REAGANOMIKA}

„Ewolucja, jaka dokonała się w polityce gospodarczej USA w latach 80. XX wieku, może być określana mianem rewolucji; tak wielce odbiegała ona od poprzednich praktyk i tradycyjnej, ortodoksyjnej ekonomii"12. Owa rewolucja to: cięcia podatkowe, zahamowanie wzrostu wydatków rządowych, zmniejszenie kontroli rządowej oraz rozsądna polityka monetarna. Te cztery punkty łącznie to „reaganomika” ${ }^{13}$. Zgodnie jednak z tematem tego artykułu główny nacisk zostanie położony na opis zmian $\mathrm{w}$ indywidualnym podatku dochodowym.

Aktami prawnymi niosącymi ze sobą zasadnicze zmiany w systemie indywidualnych podatków dochodowych, a wprowadzonymi przez administrację R.

${ }^{8}$ Skrajnym przykładem zbyt wysokich stawek podatkowych i ograniczenia w ten sposób podaży pracy jest spadek wpływów do budżetu (krzywa Laffera).

${ }^{9}$ Zjawisko znane jest jako bracket creep.

${ }^{10}$ W. Bieńkowski, Reaganomika i jej wptyw..., s. 118-120.

${ }^{11}$ Dla propagatorów nowych poglądów powiedzenie Keynesa, będące naczelnym hasłem jego poglądów - „w długim okresie i tak wszyscy będziemy martwi”, stało się anachronizmem.

${ }^{12}$ S. F. Hayward, Ewolucja polityki spoteczno-gospodarczej Stanów Zjednoczonych w latach 80. XX wieku, [w:] Amerykański model rozwoju..., s. 81.

${ }^{13}$ Ibidem, s. 82. 
Reagana były: Ustawa Podatkowa w Celu Odbudowy Gospodarczej (Economic Recovery Tax Act of 1981 - ERTA) z roku 1981 oraz Ustawa o Reformie Podatkowej (The Tax Reform Act of 1986 - TRA) uchwalona w roku $1986^{14}$. Tabela 1 przedstawia stawki i progi podatkowe dla małżeństw rozliczających się wspólnie, jakie obowiązywały jeszcze w 1981 roku (przed wejściem w życie reform podatkowych Ronalda Reagana - pierwsza kolumna), te, które obowiązywały w wyniku wprowadzenia The Economic Report of the President w roku 1982 (druga kolumna), oraz te, które funkcjonowały od roku $1987 \mathrm{w}$ wyniku wprowadzenia The Tax Reform Act (trzecia kolumna).

Od razu daje się zauważyć obniżenie krańcowych stóp podatkowych zarówno w wyniku ustawy uchwalonej w 1981, jak i w 1986 roku. Po drugie, w wyniku obu reform dokonanych za rządów Ronalda Reagana ograniczono liczbę przedziałów podatkowych $-\mathrm{z} 16$ najpierw do 13, a potem do 5 .

Znamienne $\mathrm{w}$ kontekście rozpatrywanego $\mathrm{w}$ tym artykule zagadnienia są zmiany wprowadzone przez ERTA w stosunku do ustawodawstwa wcześniejszego. Obniżeniu uległy wszystkie stawki podatkowe, jednak realnie zmiana ta była najistotniejsza dla najlepiej zarabiających. Niewiele upraszczając, można powiedzieć, że w wyniku tych zmian zniesione zostały trzy górne przedziały podatkowe, a reszta, biorąc pod uwagę stosunkową doniosłość tych zmian, pozostała taka sama.

Do innych zmian podatkowych zaliczyć należy indeksowanie przedziałów dochodowych. Celem tego zabiegu było uniknięcie sytuacji, w której inflacja powodowała przesuwanie dochodów do przedziałów o wyższym opodatkowaniu. Zjawisko to miało istotny wpływ na płacenie podatków szczególnie w latach 70., kiedy to, jak wspomniano wcześniej, miał miejsce przyspieszony wzrost inflacji. Indeksacja ta miała obowiązywać od 1985 roku. Na uwagę zasługuje też obniżenie górnej stawki podatkowej dochodów od kapitału z 28\% do $20 \%{ }^{15}$. Ma to szczególne znaczenie dla rozkładu dochodów, jeśli weźmie się pod uwagę następujące dane: 10\% najbogatszych Amerykanów pod koniec ubiegłego wieku władało 80\% nieruchomości mieszkalnych, 91\% majątku przedsiębiorstw, 85\% akcji i aż 94\% obligacji. Obniżka opodatkowania dochodów z kapitału ma zatem szczególne znaczenie jedynie dla najbogatszych ${ }^{16}$.

\footnotetext{
${ }^{14} \mathrm{~W}$ okresie rządów Reagana uchwalono też inne ustawy kształtujące system podatkowy od dochodów osobistych, jednak były to zmiany niewiele znaczące.

${ }^{15}$ W. Bieńkowski, Reaganomika i jej wptyw..., s. 156.

${ }^{16}$ T. Kowalik, Systemy gospodarcze: efekty i defekty reform i zmian ustrojowych, Fundacja Innowacja, Warszawa 2005, s. 123.
} 
Tabela 1. Stawki i progi podatkowe w Stanach Zjednoczonych dla osób pozostających w związku małżeńskim wypełniających wspólnie zeznanie podatkowe ${ }^{17}$ w roku 1981, 1982 i 1987

\begin{tabular}{|c|c|c|c|c|c|c|c|c|}
\hline \multicolumn{3}{|c|}{ Rок 1981} & \multicolumn{3}{|c|}{ ERTA - ROK 1982} & \multicolumn{3}{|c|}{ TRA - вок 1987} \\
\hline \multirow{2}{*}{$\begin{array}{l}\text { KRAŃCOWA } \\
\text { STOPA PO- } \\
\text { DATKOWA }\end{array}$} & \multicolumn{2}{|c|}{ PRZEDZIALY PODATKOWE } & \multirow{2}{*}{$\begin{array}{l}\text { KRAŃCOWA } \\
\text { STOPA PO- } \\
\text { DATKOWA }\end{array}$} & \multicolumn{2}{|c|}{ PRZEDZIALY PODATKOWE } & \multirow{2}{*}{$\begin{array}{l}\text { KRAŃCOWA } \\
\text { STOPA PO- } \\
\text { DATKOWA }\end{array}$} & \multicolumn{2}{|c|}{ PRZEDZIAŁY PODATKOWE } \\
\hline & PONAD & $\begin{array}{c}\text { NIE WIECCEJ } \\
\text { NIŻ }\end{array}$ & & PONAD & $\begin{array}{c}\text { NIE WIĘCEJ } \\
\text { NIŻ }\end{array}$ & & PONAD & $\begin{array}{c}\text { NIE WIĘCEJ } \\
\text { NIŻ }\end{array}$ \\
\hline $0,0 \%$ & $\$ 0$ & $\$ 3,400$ & $0,0 \%$ & $\$ 0$ & $\$ 3,400$ & $11,0 \%$ & $\$ 0$ & $\$ 3,000$ \\
\hline $14,0 \%$ & $\$ 3,400$ & $\$ 5,500$ & $12,0 \%$ & $\$ 3,400$ & $\$ 5,500$ & $15,0 \%$ & $\$ 3,000$ & $\$ 28,000$ \\
\hline $16,0 \%$ & $\$ 5,500$ & $\$ 7,600$ & $14,0 \%$ & $\$ 5,500$ & $\$ 7,600$ & $28,0 \%$ & $\$ 28,000$ & $\$ 45,000$ \\
\hline $18,0 \%$ & $\$ 7,600$ & $\$ 11,900$ & $16,0 \%$ & $\$ 7,600$ & $\$ 11,900$ & $35,0 \%$ & $\$ 45,000$ & $\$ 90,000$ \\
\hline $21,0 \%$ & $\$ 11,900$ & $\$ 16,000$ & $19,0 \%$ & $\$ 11,900$ & $\$ 16,000$ & $38,5 \%$ & $\$ 90,000$ & - \\
\hline $24,0 \%$ & $\$ 16,000$ & $\$ 20,200$ & $22,0 \%$ & $\$ 16,000$ & $\$ 20,200$ & & & \\
\hline $28,0 \%$ & $\$ 20,200$ & $\$ 24,600$ & $25,0 \%$ & $\$ 20,200$ & $\$ 24,600$ & & & \\
\hline $32,0 \%$ & $\$ 24,600$ & $\$ 29,900$ & $29,0 \%$ & $\$ 24,600$ & $\$ 29,900$ & & & \\
\hline $37,0 \%$ & $\$ 29,900$ & $\$ 35,200$ & $33,0 \%$ & $\$ 29,900$ & $\$ 35,200$ & & & \\
\hline $43,0 \%$ & $\$ 35,200$ & $\$ 45,800$ & $39,0 \%$ & $\$ 35,200$ & $\$ 45,800$ & & & \\
\hline $49,0 \%$ & $\$ 45,800$ & $\$ 60,000$ & $44,0 \%$ & $\$ 45,800$ & $\$ 60,000$ & & & \\
\hline $54,0 \%$ & $\$ 60,000$ & $\$ 85,600$ & $49,0 \%$ & $\$ 60,000$ & $\$ 85,600$ & & & \\
\hline $59,0 \%$ & $\$ 85,600$ & $\$ 109,400$ & $50,0 \%$ & $\$ 85,600$ & - & & & \\
\hline $64,0 \%$ & $\$ 109,400$ & $\$ 162,400$ & & & & & & \\
\hline $68,0 \%$ & $\$ 162,400$ & $\$ 215,400$ & & & & & & \\
\hline $70,0 \%$ & $\$ 215,400$ & - & & & & & & \\
\hline
\end{tabular}

Źródło: Tax Foundation, http://www.taxfoundation.org/files/federalindividualratehistory-200901021.pdf (5.09.2009).

Celem wprowadzenia w życie The Tax Reform Act była dalsza redukcja krańcowych stawek podatkowych, uproszczenie i ogólne zracjonalizowanie całego systemu podatkowego Stanów Zjednoczonych. Przedstawione w tabeli 1 stawki podatkowe obowiązywały tylko właśnie w 1987 roku, a w latach kolejnych, już za prezydentury Georga H. Busha ${ }^{18}$, ulegały dalszym redukcjom. W roku 1988

${ }^{17}$ Ograniczenie się w tym przypadku, jak i w kolejnych, do stawek podatkowych właśnie dla osób pozostających w związku małżeńskim i wspólnie rozliczających się z podatku należy uzasadnić w ten sposób, że w pozostałych grupach podatkowych zmiany wprowadzane opisywanymi w tym artykule ustawami są proporcjonalnie takie same.

${ }^{18}$ George H. Bush, który został prezydentem USA w 1989 r., był kontynuatorem polityki gospodarczej Ronalda Reagana. Stąd też zmiany w podatkach od dochodów indywidualnych, jakie wprowadzono podczas jego kadencji, w tym artykule omówione zostały w podrozdziale zatytutowanym Reaganomika. 
system podatkowy od dochodów osobistych stanowily już tylko cztery progi: 15\%, 28\%, 33\%, 28\%, a w 1991 tylko trzy: 15\%, 28\%, 31\%.

Zmiany podatkowe, jakie miały miejsce podczas prezydentury Ronalda Reagana oraz jego następcy i kontynuatora jego polityki - George'a H. Busha, były odzwierciedleniem ówczesnych trendów w teorii ekonomii. Obniżki podatków, jakie nastąpiły w tamtym okresie, były najbardziej radykalne w całym okresie od powołania federalnego systemu podatkowego w 1913 roku $^{19}$. Największe korzyści odniosły jednak te grupy społeczeństwa, które należały do najzamożniejszych. Tadeusz Kowalik o okresie rządów Ronalda Reagana i George’a H. Busha pisze jednoznacznie i dosadnie: „Ideologią czy też duchem nowego czasu (Zeitgeist) staje się neoliberalizm, czyli apoteoza skrajnie pojmowanego wolnego rynku. Rozpoczyna się długi okres wzrostu nierówności dochodowych (i majątkowych)”20.

\section{„CLINTONOMICS"21}

Mimo że Bill Clinton pochodził z przeciwnego republikanom obozu politycznego, efekty jego prezydentury określa się bardziej jako kontynuację polityki jego dwóch poprzedników niż jej negację. Było to wynikiem złożonej i niepewnej sytuacji w ówczesnym parlamencie zaraz po wyborach, a potem także przewagi republikanów w Kongresie po wyborach w 1994 roku $^{22}$. Joseph Stiglitz, ówczesny przewodniczący Rady Doradców Ekonomicznych prezydenta Billa Clintona, następującymi słowami opisuje tamtą sytuację: „Bill Clinton był człowiekiem czynu, ale bez aprobaty Kongresu miał związane ręce. Tylko wtedy, gdy jego zamierzenia były zgodne z zamysłami republikanów, mógł coś zrobić”³.

Mimo takiej sytuacji politycznej udało się jednak wprowadzić zmiany w podatku dochodowym od osób fizycznych. Podwyżka podatków podyktowana była rosnącym deficytem, będącym spuścizną po rządach i reformach podatkowych Ronalda Reagana i George'a H. Busha. Wbrew przewidywaniom obu prezydentów i podażowej szkoły ekonomii, dynamiczne skutki obniżenia podatków, czyli wzrost aktywności gospodarczej i mający być tego skutkiem wzrost wpływów do budżetu, nie nastąpiły (lub ich efekty były zbyt słabe). Pociągnęło to za sobą znaczący wzrost deficytu budżetowego ${ }^{24} \mathrm{i}$ administracja Billa Clintona wyszła $\mathrm{z}$ ini-

${ }^{19}$ S. G. Kozłowski, Ameryka wspótczesna: pejzaż polityczny i spoteczno-gospodarczy, Wydawnictwo Uniwersytetu Marii Curie-Skłodowskiej, Lublin 2008, s. 354.

${ }^{20}$ T. Kowalik, Systemy gospodarcze..., s. 116-117.

${ }^{21}$ Określenie T. Kowalika; ibidem, s. 118.

${ }^{22}$ Ibidem.

${ }^{23}$ J. E. Stiglitz, Szalone lata dziewięćdziesiąte, Wydawnictwo Naukowe PWN, Warszawa 2006, s. 169.

${ }^{24}$ W 1992 r. deficyt wynosił już 297,7 mld USD, a w roku 2000 zanotowano nadwyżkę w wy- 
cjatywą zrównoważenia budżetu. Zgodnie $\mathrm{z}$ założeniem ówczesnej administracji rządowej główny ciężar podwyżek podatków poniosły te osoby, które najbardziej skorzystały ze wzrostu gospodarczego i dokonanych wówczas obniżek podatków w latach 80 . Wzrost stawek podatkowych objął jedynie 1,2\% ogółu podatników i były to osoby o najwyższych dochodach ${ }^{25}$. Zmiany podatkowe wprowadzono ustawą The Omnibus Budget Reconciliation Act of 1993. W porównaniu z rokiem poprzednim nowe stawki kształtowały się następująco:

Tabela 2. Stawki i progi podatkowe w Stanach Zjednoczonych dla małżeństw wypełniających wspólnie zeznanie podatkowe w roku 1992 i 1993

\begin{tabular}{|c|c|c|c|c|c|}
\hline \multicolumn{3}{|c|}{ ROK 1992} & \multicolumn{3}{c|}{ OBRA - ROK 1993 } \\
\hline \multirow{2}{*}{$\begin{array}{c}\text { KRANंCOWA STOPA } \\
\text { PODATKOWA }\end{array}$} & \multicolumn{2}{|c|}{ PRZEDZIALY PODATKOWE } & \multirow{2}{*}{$\begin{array}{c}\text { KRAŃCOWA STOPA } \\
\text { PODATKOWA }\end{array}$} & \multicolumn{2}{|c|}{ PRZEDZIALY PODATKOWE } \\
\cline { 2 - 3 } & PONAD & NIE WIĘCEJ NIŻ & PONAD & NIE WIĘCEJ NIŻ \\
\hline $15,0 \%$ & $\$ 0$ & $\$ 35,800$ & $15,0 \%$ & $\$ 0$ & $\$ 36,900$ \\
\hline $28,0 \%$ & $\$ 35,800$ & $\$ 86,500$ & $28,0 \%$ & $\$ 36,900$ & $\$ 89,150$ \\
\hline $31,0 \%$ & $\$ 86,500$ & - & $31,0 \%$ & $\$ 89,150$ & $\$ 140,000$ \\
\hline & & & $36,0 \%$ & $\$ 140,000$ & $\$ 250,000$ \\
\cline { 5 - 6 } & & & $39,6 \%$ & $\$ 250,000$ & - \\
\hline
\end{tabular}

Źródło: Tax Foundation, http://www.taxfoundation.org/files/federalindividualratehistory-200901021.pdf (5.09.2009).

W stosunku do 1992 roku wprowadzono dwie nowe stawki podatkowe - 36\% i 39\%, oraz przede wszystkim dwa nowe przedziały podatkowe, podwyższające podatki dla najbogatszych. Wprowadzono także zwolnienia z podatku dochodowego dla większości obywateli zarabiających poniżej średniej ${ }^{26}$. Zmiany podatkowe za prezydentury Billa Clintona, mimo motywacji skierowanej ku zrównoważeniu budżetu, przyniosły wyższe obciążenie podatkami grup najlepiej zarabiających.

sokości 189,5 mld USD. Zob. W. A. Niskanen, Polityka gospodarcza administracji Billa Clintona, [w:] Amerykański model rozwoju..., s. 100.

${ }^{25}$ J. E. Stiglitz, Ekonomia sektora publicznego, Wydawnictwo Naukowe PWN, Warszawa 2004, s. 647-648.

${ }^{26}$ W. A. Niskanen, op. cit., s. 102. 


\section{GEORGE W. BUSH}

Jak pisze W. Bieńkowski, polityka ekonomiczna G. W. Busha była nie tylko kontynuacją polityki zainicjowanej przez Ronalda Reagana w latach 80. W wielu punktach G. W. Bush poszedł nawet dalej w redukowaniu roli państwa w gospodarce. $\mathrm{W}$ duchu reaganomiki i szkoły podażowej zostały także przeprowadzone reformy podatkowe ${ }^{27}$. Tak jak za prezydentury Ronalda Reagana zostały obniżone stawki podatkowe dla najlepiej zarabiających. Zmiany podatkowe George'a W. Busha wprowadzone były ustawami: The Economic Growth and Tax Reform Reconciliation Act of 2001 oraz Jobs and Growth Tax Relief Reconciliation Act of 2003. Ostatecznym efektem tych zmian było obniżenie dwóch najwyższych stawek podatkowych - z 39,1\% do $35 \%$ i z $36 \%$ do $33 \%$.

Według kongresowego biura budżetu (CBO) 1\% najbogatszych Amerykanów, których średnie dochody wynoszą 1,2 mln dolarów rocznie, w 2004 roku uzyskał zmniejszenie federalnego podatku średnio o 78 tys. dolarów. Obciążenie podatkowe 400 najbogatszych Amerykanów w porównaniu z rokiem 1993 zmniejszyło się o 40\%. Dla porównania w 2004 roku dolny kwintyl (najbiedniejsze 20\% ludności) o średnich dochodach w wysokości 16620 dolarów uzyskał zmniejszenie obciążenia podatkowego jedynie o 250 dolarów. Według szacunków Institute on Taxation an Economic Policy aż 37,6\% łącznej wartości obniżek podatkowych od początku prezydentury G. W. Busha do 2010 roku trafi do $1 \%$ najbogatszych Amerykanów (a 68,2\% do najbogatszego kwintyla) ${ }^{28}$.

Zmian opodatkowania dochodów z kapitału dokonano w 2003 roku. Podatek od dywidendy zmniejszono z $35 \%$ do poziomu 15\%. Także do $15 \%$ obniżono opodatkowanie od zysków ze sprzedaży akcji ${ }^{29}$.

Podsumowanie zmian w opodatkowaniu dochodów osobistych w Stanach Zjednoczonych przedstawia wykres 1 . Wyraźnie na nim widać stopniowe obniżanie ciężaru podatkowego $\mathrm{z}$ biegiem lat. Jak już zaznaczono wcześniej, a co graficznie potwierdza wykres, najbardziej znaczące były zmiany wprowadzone przez republikańskich prezydentów - Ronalda Reagana i George’a H. Busha.

Wykres wskazuje również, że jedyną reformą podatku od dochodów osobistych zwiększającą ciężar opodatkowania grup lepiej zarabiających była Omnibus Budget Reconciliation Act of 1993 wprowadzona przez administrację Billa Clintona. George W. Bush w 2003 roku zredukował jednak stawki podatkowe dla naj-

${ }^{27}$ W. Bieńkowski, Czy polityka George'a W. Busha jest kontynuacja reaganomiki?, [w:] Amerykański model rozwoju..., s. 87.

${ }^{28}$ S. G. Kozłowski, op. cit., s. 354-355.

${ }^{29}$ Ibidem. 
bogatszych. Dziś system podatkowy w Stanach Zjednoczonych wyraźnie uprzywilejowuje bogatych ${ }^{30}$

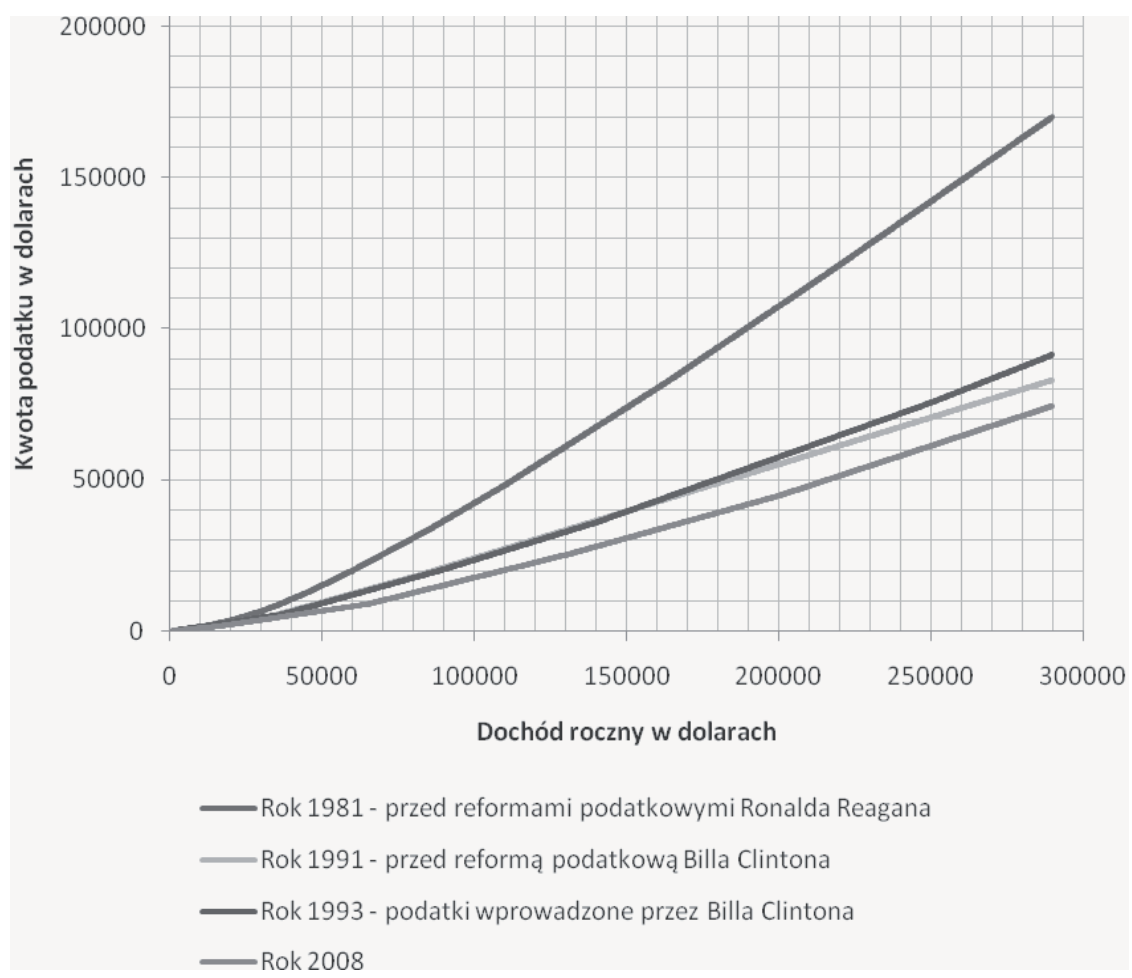

Wykres 1. Kwoty podatku dochodowego dla danej wysokości dochodu rocznego w roku 1981, 1991, 1993 i 2008

Źródło: opracowanie własne na podstawie Tax Foundation.

\section{PORÓWNANIE ZMIAN PODATKOWYCH ZE WSKAŹNIKAMI ROZKŁADU DOCHODÓW}

Wykres 2 przedstawia wartość współczynnika Giniego dla amerykańskich gospodarstw domowych w latach 1975-2008 z zaznaczonymi datami opisanych wyżej reform podatkowych ${ }^{31}$. Czy widoczne są zmiany wartości tego współczynnika w następstwie wprowadzanych reform podatkowych? Na pewno są widoczne dla opodatkowania, jakie zostało wprowadzone w 1991 roku (liczba 3 na wykresie 2). W USA funkcjonowały wówczas skrajnie niskie podatki i wydaje się, że wła-

${ }^{30}$ Ibidem, s. 354.

31 1. Economic Recovery Tax Act of 1981; 2. The Tax Reform Act of 1986; 3. Stawki funkcjonujące w 1991 roku; 4. The Omnibus Budget Reconciliation Act of 1993; 5. Stawki po reformach George'a W. Busha. 
śnie w związku z tym nastąpił znaczący i bardzo szybki wzrost nierówności dochodowych (wzrost współczynnika Giniego w latach 1991-1993). Także widoczne, ale już tylko ze względu na zmianę kierunku, a nie na ich wielkość, wydają się zmiany wprowadzone w 1993 roku przez Billa Clintona (liczba 4 na wykresie 2). Przejawia się to w zauważalnym spadku wartości współczynnika Giniego, jednak jest to spadek krótkotrwały i już od roku 1995 wartość współczynnika powraca do trendu rosnącego. Zgodnie $z$ intuicją obniżki podatków z lat 1981, 1986 i 2003 prowadzą do wzrostu współczynnika Giniego, jednak nie są to wzrosty będące odwróceniem wcześniejszego trendu spadkowego bądź też wzrosty o szczególnej sile, by wiązać je w sposób jednoznaczny właśnie $\mathrm{z}$ wprowadzanymi zmianami opodatkowania dochodów.

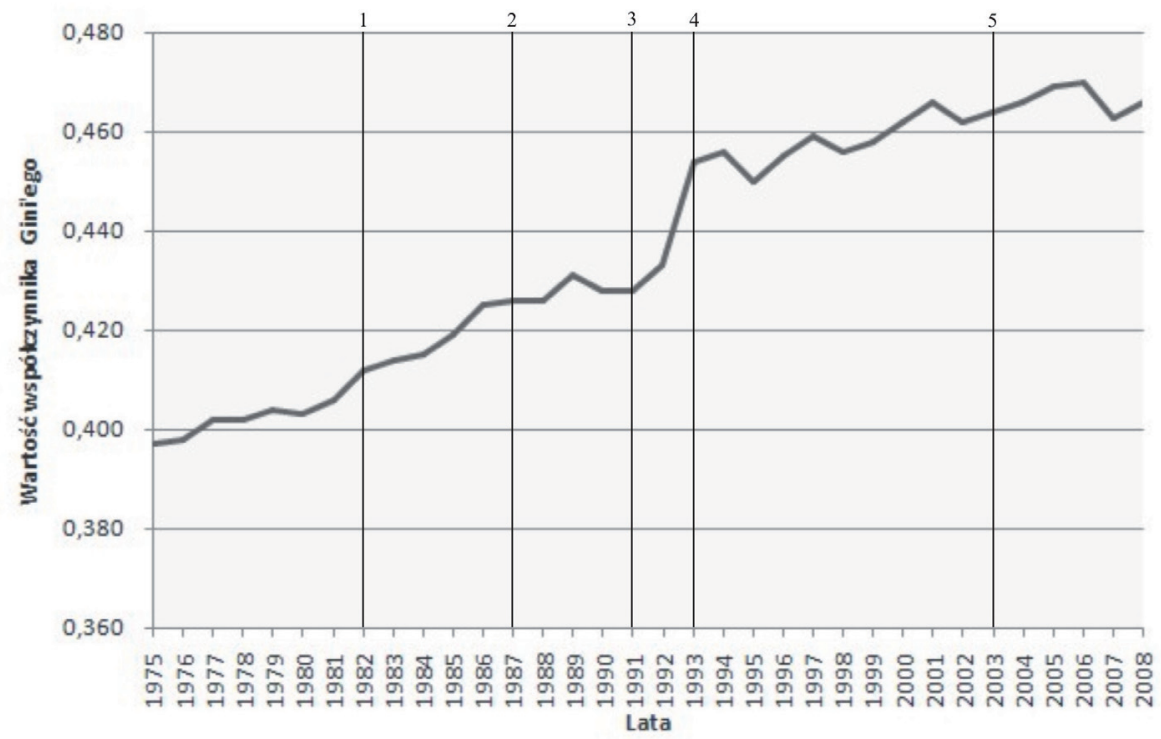

Wykres 2. Współczynnik Giniego dla Stanów Zjednoczonych w latach 1975-2008 z zaznaczonymi najważniejszymi reformami podatków od dochodów indywidualnych Źródło: opracowanie własne na podstawie danych Census Bureau i Tax Foundation.

Ciekawych wniosków dostarcza analiza statystyczna wartości współczynnika Giniego w latach 1975-2008. Jego wartość od 1975 do 2008 roku wzrosła o 17,38\%, a średnie tempo wzrostu wynosiło 0,493\%. Najbardziej znaczący wzrost, jak już wcześniej wspomniano, miał miejsce w latach 1991-1993. W tym okresie wartość współczynnika wzrosła aż o blisko 6,1\%. Największe spadki miały miejsce w latach 1995 i 2007 - odpowiednio o 1,3\% i 1,5\% w stosunku do roku 
poprzedniego. Współczynnik zmienności, który wynosi $1 \%^{32}$, wskazuje, że poszczególne wartości rocznych stóp zmian bardzo nieznacznie różnią się od ich wartości średniej. Świadczy to o prawie stałym tempie wzrostu nierówności dochodowych, które nie wykazuje reakcji na zmiany w polityce podatkowej.

Do podobnych wniosków prowadzi wykres 3 przedstawiający udział w dochodach poszczególnych grup rodzin. Jedyny wyraźny wpływ, jaki można tu wyodrębnić, to stosunkowo znaczący wzrost udziału ostatniego kwintyla i górnych $5 \%$ rodzin w dochodach na skutek zmian podatkowych w 1991 roku (3 na wykresie 3 ) i zahamowanie tempa tego wzrostu w roku 1993 (4 na wykresie 3). Pozostałe zmiany podatkowe nie wpłynęły w sposób znaczący na zmianę trendu wartości poszczególnych współczynników czy choćby na zmianę tempa ich wzrostu bądź spadku. Tendencja wzrostu udziału w dochodach ostatniego kwintyla i górnych $5 \%$ rodzin oraz spadku udziału pierwszych czterech kwintyli ma miejsce przez cały okres lat 1975-2008.

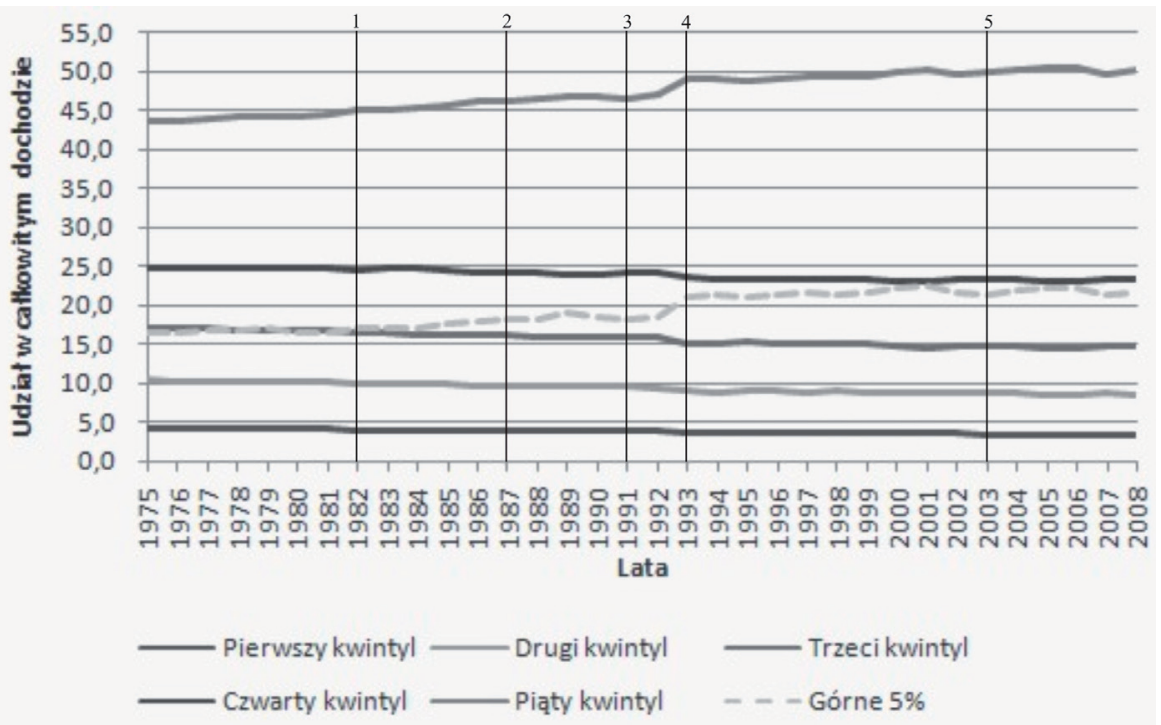

Wykres 3. Udział w zagregowanym dochodzie uzyskany przez poszczególne grupy gospodarstw domowych w Stanach Zjednoczonych w latach 1975-2008 z zaznaczonymi kluczowymi w tych latach reformami w podatku od dochodów indywidualnych

Źródło: opracowanie własne na podstawie danych Census Bureau i Tax Foundation.

32 Po wykluczeniu wartości skrajnych, tj. odpowiednich dla lat 1991-1993, 1995 i 2007, wartość współczynnika zmienności wynosi 0,58\%. 
Tabela 3 przedstawia zmiany udziału poszczególnych kwintyli i górnych 5\% gospodarstw domowych w zagregowanych dochodach w Stanach Zjednoczonych w latach 1975-2008.

Tabela 3. Zmiany udziału poszczególnych kwintyli i górnych 5\% gospodarstw domowych w zagregowanych dochodach w Stanach Zjednoczonych w latach 1975-2008

\begin{tabular}{|l|c|c|c|c|c|c|}
\hline \multicolumn{1}{|c|}{ KWINTYLE } & \multicolumn{1}{|c|}{ I } & II & III & IV & V & $\begin{array}{c}\text { GónNE } \\
5 \%\end{array}$ \\
\hline $\begin{array}{l}\text { Zmiana w udziale w dochodach } \\
\text { w latach 1975-2008 }\end{array}$ & $-20,93 \%$ & $-17,31 \%$ & $-13,53 \%$ & $-5,67 \%$ & $14,68 \%$ & $30,30 \%$ \\
\hline Średnie tempo zmian & $-0,7 \%$ & $-0,57 \%$ & $-0,43 \%$ & $-0,17 \%$ & $0,42 \%$ & $0,84 \%$ \\
\hline $\begin{array}{l}\text { Współczynnik zmienności tem- } \\
\text { pa zmian }\end{array}$ & $1,63 \%$ & $1,19 \%$ & $1,03 \%$ & $0,82 \%$ & $0,92 \%$ & $2,87 \%$ \\
\hline
\end{tabular}

Źródło: opracowanie własne na podstawie danych Census Bureau i Tax Foundation.

Udział w dochodach w latach 1975-2008 zwiększył się tylko w piątym kwintylu gospodarstw domowych oraz w 5\% gospodarstw o najwyższych dochodach. W pozostałych grupach ten udział spadł. Współczynnik zmienności wskazuje, że tempo zmian rok po roku w udziale gospodarstw domowych w sumie dochodów było bardzo zbliżone do swojej wartości średniej. Stąd też wnioskować można znikomy wpływ zmian podatkowych, które - jak wykazano wcześniej - były znaczące, na udział w całym dochodzie poszczególnych grup gospodarstw domowych. Najbardziej znaczące zmiany miały miejsce w latach:

- 1981-1982, kiedy nieco bardziej niż średnio widoczny był spadek udziału w dochodach pierwszych trzech kwintyli; podobna sytuacja miała miejsce w latach 1985-1986, ale tym także towarzyszy wzrost udziału w dochodach grup najbogatszych;

- 1992-1993, kiedy to udział pierwszego kwintyla w sumie dochodów w stosunku do roku poprzedniego spadł o ponad 5,3\%, piątemu kwintalowi wzrósł o 4,5\%, a górnym 5\% gospodarstw domowych wzrósł o 16\%;

- w 2002 i 2007 roku, kiedy doszło do zmniejszenia udziału w dochodach 5\% najbogatszych gospodarstw domowych, odpowiednio o 3,1\% i 4,9\%.

\section{ZAKOŃCZENIE}

Wzrost nierówności dochodowych, jaki dokonał się w Stanach Zjednoczonych w latach 1975-2008, jest bardzo znaczący. Według klasyfikacji Human Develop- 
ment Report 2007/2008 USA, wśród krajów najbardziej rozwiniętych ${ }^{33}$, mają niższy współczynnik Giniego tylko od następujących krajów: Hongkong, Singapur, Argentyna, Chile, Urugwaj, Costa Rica, Meksyk, Panama, Malezja i Brazylia ${ }^{34}$.

Przeprowadzona wyżej analiza prowadzi do zasadniczego wniosku - zmiany polityki podatkowej raczej nie wpływają w sposób jednoznaczny na wskaźniki rozbieżności dochodowych. Wyjątkiem są tu zmiany z 1991 roku, kiedy to opodatkowanie dochodów osobistych można uznać za stosunkowo skrajnie niskie i przez to wpływ ten jest zauważalny. Niewielki wpływ można także zanotować dla zmian w 1993 roku. Prawie żadnym zmianom podatkowym nie udało się jednak odwrócić trendu wzrostu rozbieżności dochodowych, który wydaje się prawie w ogóle nie reagować na politykę podatkową państwa. To prowadzić może do wniosku, że mimo funkcjonowania w Stanach Zjednoczonych progresywnej skali podatkowej, rozbieżności dochodowe powiększają się w szybkim tempie. Przyczyną może być tu zbyt niska progresja stawek podatkowych. Chęć skuteczniejszego oddziaływania na zmniejszenie rozbieżności dochodowych wymagałaby dużo bardziej progresywnej skali podatkowej.

Powyższe wnioski korespondują z konkluzjami przywołanymi przez Tadeusza Kowalika. Dla całego trzydziestolecia rozwoju wschodniej Azji nie potwierdza się teza Kuznetsa mówiąca, że wraz ze wzrostem gospodarczym rosną rozbieżności dochodowe, ale tylko początkowo. $Z$ czasem tendencja ta miałaby się odwrócić i miałoby następować zmniejszenie nierówności dochodowych w społeczeństwie $^{35}$. Tożsame przypuszczenia, w obliczu przeprowadzonej analizy, mogą być formułowane wobec Stanów Zjednoczonych. Prawie nieustanny wzrost gospodarczy w latach 1975-2008 w tym wysoko rozwiniętym kraju nie doprowadził do zmniejszania się różnic dochodowych pomiędzy poszczególnymi grupami społeczeństwa, a doprowadził do ich wzrostu.

Powracając do tematu przewodniego niniejszego wydawnictwa - ułomność rynku a ułomność państwa, należy odpowiedzieć, którymi z tych ułomności są nierówności dochodowe. Wydaje się, że odpowiedź jest złożona. Po pierwsze, mówiąc o sprawiedliwości podziału dochodów w kontekście rynku, nie należy odwoływać się do wszelkich koncepcji normatywnych sprawiedliwości. Rynek ma „swoją sprawiedliwość” i według niej dzieli dochody. Normy moralne i etyczne zdają się tu nie działać.

${ }^{33}$ Podział na trzy grupy krajów: High human development, Medium human development i Low human development. Stany Zjednoczone zalicza się do grupy pierwszej.

${ }^{34}$ Należy dodać, że ta grupa państw zawiera ich 70, z czego tylko wymienionych 10 ma wyższy współczynnik rozpiętości dochodowych (współczynnik Giniego). Human Development Report 2007/2008, United Nations Development Programme, s. 281-282.

${ }^{35}$ T. Kowalik, Nowe tendencje w świecie, [w:] T. Kowalik (red.), Nierówni i równiejsi, Fundacja Innowacja, Warszawa 2006, s. 16-18. 
Można jednak do tego zagadnienia podejść nieco inaczej. Realny dochód pierwszego kwintyla ludności w cenach stałych z 2008 roku w okresie 1975-2008 wzrósł o 0,1\%, kwintyla drugiego o 13,5\%, trzeciego o 23,3\%, czwartego o 37,8\%, piątego o $65,2 \%$, a najbogatszych $5 \%$ rodzin o $93,4 \%$. Według danych U.S. Department of Commerce realny dochód narodowy brutto w Stanach Zjednoczonych w okresie 1975-2008 zwiększył się 2,72 razy $^{36}$.Czy w tak wielkim sukcesie gospodarczym udział poszczególnych grup ludności jest adekwatny do wzrostu ich realnych wynagrodzeń? Czy nie jest to ułomność rynku?

Można także zapytać w tym kontekście o ułomność państwa. Tak jak stwierdzono na początku artykułu, redystrybucyjna rola finansów publicznych jest jednym $z$ uzasadnień pobierania przez państwo podatków. Niewątpliwie rząd Stanów Zjednoczonych prowadzi politykę redystrybucji dochodów, jednak czy wobec przytoczonych danych o wzrastających wciąż nierównościach dochodowych polityka ta nie jest porażką? Jeśli tak, to jest to jawna ułomność działania państwa.

\title{
INCREASE IN THE AMERICAN SOCIETY INCOME INEQUALITIES AND THE UNITED STATES TAX POLICY IN 1975-2008
}

\author{
SUMMARY
}

The article presents the tax policy of every president of the United States in 1975-2008. Starting from the period which is previous to Ronald Reagan's reforms, which is assumed as a starting period of carried analysis, through Reaganomics, Bill Clinton's reforms, up to the changes introduced by George W. Bush, individual income tax reforms are presented. Individual changes are compared to American families income inequalities index.

\footnotetext{
${ }^{36}$ U.S. Department of Commerce, Bureau of Analysis.
} 
